\title{
Describing the Need for Affordable Livable Sustainable Housing Based on Maslow's Theory of Need
}

\author{
Dr. Shadiya Mohamed Saleh Baqutayan \\ Dr. Aini Suzana Binti Ariffin \\ Dr. Fauziah Raji
}

Perdana School of Science, Technology and Innovation Policy, University technology Malaysia International campus, Malaysia shadiya.kl@utm.my

Doi:10.5901/mjss.2015.v6n3s2p353

\begin{abstract}
Housing plays an important role in people's wellbeing, contributing to the physical and psychological health, safety and security outcomes, and love and belongingness need. But the major challenge in this context is the establishment of adequate, affordable, livable and sustainable housing standards for the population. Although the sustainable housing was a big issue to researchers, practitioner and policy maker for some considerable time, and more recently attention has been drawn to the issue of declining affordability in housing. The main problem in this subject has always been in identifying the affordable, sustainable and livable home standards for societal wellbeing. Because researchers believe that there is a gap existed between affordable, livable and sustainable home criteria. Therefore, this study presents a research on the importance of housing to the people. It examines on how certain standards need to be encountered in housing for the societal wellbeing. The purpose is to present an overview of livable affordable housing definition and to relate that to Maslow theory of need so that the gap between the terms will be connected. Data was gathered from fifty respondents, using "housing criteria questionnaires". The result indicated that housing need to be adequate basic standard that is safe and secure, provides reasonable access to work opportunities and community services and that is available at a cost, which does not cause substantial hardship to the occupants. Eventually, the outcomes can help researchers, planners, architects, policy makers and others in the formulation of housing criteria guidelines for the introducing of quality housing as part of the effort to incorporate these features into any new housing projects, so that the citizen will continue to enjoy the benefits of adequate, affordable livable and sustainable housing.
\end{abstract}

Keywords: Affordable housing, livable home, sustainable house, Maslow Theory of need

\section{Introduction}

Since the past few years, housing has improved for many people. Homeowners have seen the value of their properties increase and the social tenants have seen massive improvements in the quality of their homes. But the new challenges we are facing today are the house prices that have grown faster than wages. It is becoming increasingly difficult for young people to get a step on the housing ladder. And the challenges of climate change mean we need to provide good quality and better-designed housing for the future. Nevertheless, how to get a good quality house with affordable price? Can we have our dream house according to the amount of money we earn monthly? Are those affordable housing livable? From this point, we can say that there is a gap between affordable housing and livable one. Those affordable houses might not be livable or/and sustainable at all. Before going deeply into this matter, let us see first what do we mean by affordable, livable and sustainable housing? How these are related to Maslow theory of need? Are there any gaps between these terms? What are the gaps and how to bridge these gaps?

\section{Literature Review}

Everyone have the right to live in house that meets his/her needs. The essential to achieve this standard is through accessing to adequate housing. Housing is a basic human need that Maslow explained in the hierarchy of needs as a first important level of need similar to food and drink; therefore, it is at the centre of wellbeing (Manitoba, 2012); People must have food to eat, water to drink and a place to call home before they can think about anything else (Martin \& Joomis, 2007). Furthermore, Maslow's theory demonstrates also how important adequate housing is for the security and positive 
development, and this is the second level of need; people must possess the security of a home and family in order to achieve the higher stage of need "self-actualization" (Martin \& Joomis, 2007). But the important questions are how many of us own a house? How much these houses are affordable? What does affordable at first place means? And how significant that affordable housing is livable?

According to Bhatta (2009) "affordable housing is housing deemed affordable to those with a median household income". Milligan et al. (2007) identified it as "housing that is appropriate for the needs of a range of low to moderate income households and priced so that low and moderate incomes are able to meet their other essential basic living costs". More recent definitions are broader, and introduced by Maribyrnong City Council (2008), as "The well - located energy efficient housing, appropriate to the needs of a given household, (including access to transport, goods and services and employment) where the cost (whether mortgage repayment or rent) is no more than $30 \%$ of that household's income. Housing costs exceeding this per cent creates 'housing stress', particularly for people in the lower $40 \%$ of the income distribution scale".

Furthermore, the Canada Mortgage \& Housing Corporation (2008), identify 'affordable housing' as shelter which costs no more than $30 \%$ of one's total income. Affordable housing is broadly defined as housing that can be provided at a reasonable cost when compared to income, typically that which can be provided at no more than $30 \%$ per cent of gross household income for households with very low to moderate incomes. Based on these definitions, the low-and-middle income group does not have the alternatives to choose for a quality house, and they do not have many options to rent or buy an affordable house in the location that they like due to financial constraints.

The ratio of house prices to income is a key indicator of the relative affordability of the owner occupation. It is stated by HIA Economics Group (2010), that a house price to income ratio is the ratio of average or median house prices to average or median gross or disposable income in a given geographical area. The ratio is used as one measure of trends in housing affordability over time. Bogdon and Can (1997) criticized the affordability literature that is only focusing on house prices rather than the condition, location and neighborhood characteristics of the housing. However, even today the majority of tools used to assess affordability have little or no regard for housing quality, location and neighborhood characteristics, i.e. what households get in return for what they spend on housing. But the question out of this discussion is how much these houses that deems affordable to be livable? What are the criteria of hose livable home? What does livable at first place means?

Detailing the theory of Maslow "hierarchy of need" on this study, affordability as stated earlier is the first level of need and livability is considered the second level, as it is focusing more on safety and security. Furthermore, if there is no affordable housing; where will livability come? Livability reflects the wellbeing of a community and comprises many characteristics that make a location a place where people want to live now and in the future" (Victorian Competition and Efficiency Commission, 2008). However, livability has been defined as "a statement of desires related to the contentment with life in a particular location..." (Chazal, 2010), and also described as "a behavior-related function of the interaction between environmental characteristics and personal characteristics" (Pacione, 1990).

Indeed, Lowe, et al, (2013), conceive a livable house as a place to be one that is safe, attractive, socially cohesive and inclusive, and environmentally sustainable; with affordable and diverse housing linked to employment, education, public open space, local shops, health and community services, and leisure and cultural opportunities; via convenient public transport, walking and cycling infrastructure. However, there is an argument that an area is not truly livable unless it can be sustained over the long term (Chazal, 2010). In recent years there has been much talk of the need for sustainable houses and communities. But what is sustainability in that sense? Why sustainability is important? What are the implications of debates around sustainability for community policy and practice?

Undeniably, while affordability is mostly defined in economic terms, livability is more on individual safety. Sustainable defined as: "development that meets the needs of the present generation without compromising the ability of future generations to meet their own needs" (World Commission on Environment and Development, 1987). In 1996, the International Council of Local Environmental Initiatives ICLEI (cited in Meyers 2006, p. 105) defined sustainable development as "Development that delivers basic environmental, social and economic services to all residences of a community without threatening the viability of natural, built and social systems". Sustainability is mainly defined as "people/neighbors continuing to want to live in the same community, both now and in the future" (Long and Hutchins, 2003). In respect to the above definitions, sustainability is higher level of need, the needs that is associated with love and belonging. These needs are met through satisfactory relationships with neighbors and community surrounding the house. And it is achievable in situations where people continue to choose to live, work and carry on activities in the same common locality and community with fully occupied housing.

Based on the above definition, researchers try to develop a theoretical framework, by drawing strong relationships between the above three terms (affordable housing, livable home and sustainable house) and Maslow's theory of need, 
as indicated in the following diagram:

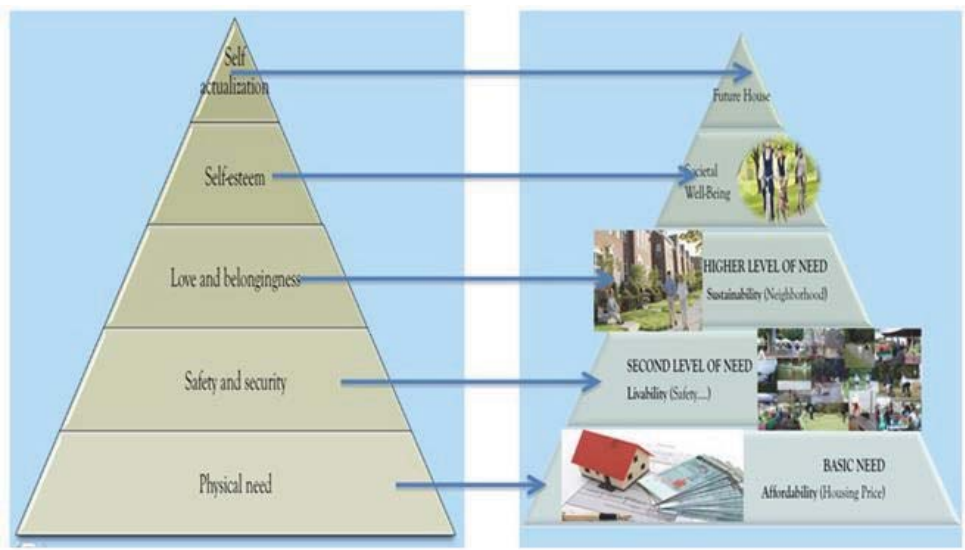

Diagram 1: The Need For Affordable Livable Sustainable Housing Based on Maslow Theory of Need

Thus, the aim of this paper is to bridge the gap between affordable housing, livable and sustainable home, taking into account the theory of Maslow. While affordability is mostly focusing on economic terms and livability on personal safety, sustainability extends to reflect social wellbeing and environmental attributes. With this in mind, researcher concludes that Maslow theory of need is highly relevant to this study and the three level of need are the objectives of this study.

\section{Methodology}

Simple random sampling was used to conduct the survey that measures housing criteria and the level of need. The questionnaire was distributed to a large number of potential participants from different areas in Kuala Lumpur (biggest city in Malaysia - population 5 million).

\section{Findings And Results}

The scale used on this study focuses on different housing criteria that are grouped under three categories: affordable, livable and sustainable housing. Frequency was conducted to calculate the level of need for housing; the percentage of respondents' answer to all questions was calculated. And lastly Multiple Regression was conducted to measure the relationship between the three variables. The results were highlighted as followed:

\subsection{Affordable Housing}

To measure the affordable housing, researcher looked into the importance of housing price to income ration, and outcome was highlighted in figure 1:

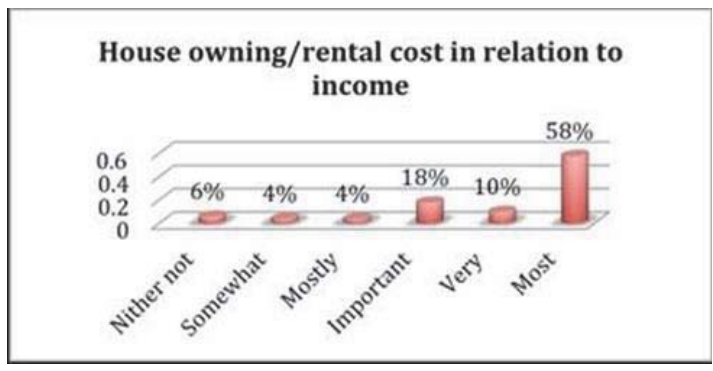

Figure 1: The Importance Of Housing Price

The above graph indicated that large number of participants (86\%) agreed that housing affordability is important to most 
important need for Malaysia population. And more than half of participants (58\%) agreed that affordable housing is the most important need. This is because the majority are facing housing bubble and extreme increase in the price of the houses. Housing considered the single largest expenditure in most household budgets, it costs directly affect financial security. Today, more than half of Malaysia population face affordable housing issue as they pay more than $30 \%$ percent of their income for housing that may or may not fit their needs. Therefore, this issue needs an urgent solution, because if people have difficulty to own a house they will not feel safe and they will not be able to move into the next level of housing that is livability. And the housing gap will be in the road as it is going to be in the first level.

\subsection{Livable Home}

Furthermore, measuring the livability of the house, researcher looked into the importance of the home safety and security, putting into accounts the availability of public transportation, school, shops, health services, and childcare. Overall outcome was highlighted in figure 2 :

Figure 2: Home Safety and Security

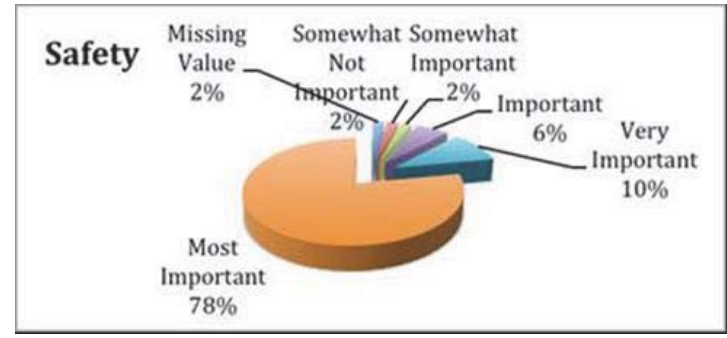

The above figure (2) indicated that large number of participants (78\%) essential to home safety, and to them safety is the most important needs. As every family aspire to live in a decent house that he/she can afford, in a community with safe streets, good schools and attractive public spaces. Unfortunately, millions of low-and-middle-income families across the nation live in housing they cannot afford in place that is unsafe with neighbors who are unsightly.

\subsection{Sustainability}

Additionally, sustainability was measured by looking into the importance of selecting the right neighborhood to stay with, and outcome was highlighted in figure 3 :

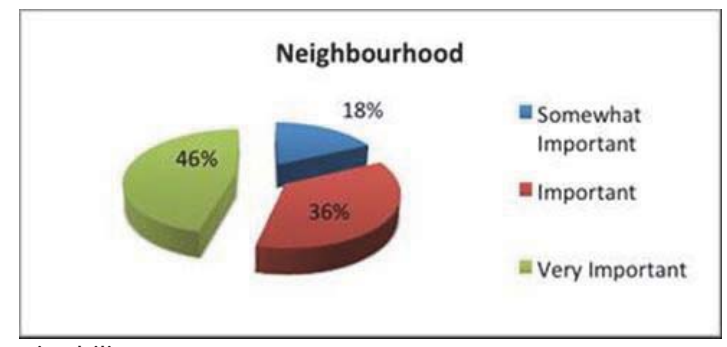

Figure 2: Neighborhood And Sustainability

The above figure indicated that almost all participants considered neighborhood as the core need for housing; $46 \%$ per cent of the population indicated neighborhood as very important need, $36 \%$ per cent as important and $18 \%$ per cent as somewhat important. This outcome show that the need to have a safe and secure place that is surrounded and protected by a healthy family and neighbor is the ultimate means of all people. Because it is stated in several studies that remaining within the same neighborhood may provide a measure of stability, allowing children to enjoy same friends and parents to continue to rely on familiar support networks. In conclusion, Housing is a basic human need that provides the safety and stability that enables individuals and families the opportunity to thrive. And the outcome of this research support this idea, as stated in Maslow theory of need; housing is very important need for all people, it contributes basically to the physical, psychological and emotional wellbeing of the person. Without housing people will not be having the place to stay, the safety they require and the love and belongingness they need. 


\section{Conclusion}

Although much remains to be learned, the current research offers strong support for the view that affordable livable home is major challenges currently facing many people across the globe. The major challenge is how to fulfill the need of every individual in regards to the housing. To detail up this, the demand for affordable livable sustainable housing based on Maslow's theory need to be highlighted. Thus the ultimate need based on the current research is sustainability (almost all respondents), then livability (78\%) comes second, and affordability (58\%) is the last important need. Indeed, and according to the outcomes of this research, the need for love and belongingness is the uppermost need, and the livability as well as affordability is lowermost need. When the neighbors are good and the house is sustainable, definitely dwellers will feel that the house is livable. Psychologically, the affordability is the lowest need followed by livability and last is the sustainability. Furthermore, the findings of this study clearly indicated the followings: (a) majority of the respondents need houses that is sustainable; (b) sustainability is the fundamental need for all residents; (c) sustainability covers good neighborhood; (d) livability is the second important need for all dwellers; (e) livability covers safety and security in and around the house; ( $f$ ) people need housing that is affordable and available at a cost which does not cause substantial hardship to the occupants. Given these points, the present research findings can be used to formulate of criteria guidelines for the introducing of quality housing; a house of an adequate basic standard that is safe and secure, provides reasonable access to work opportunities and community services, surrounded with neighbors of dwellers own choice and that is available at a cost which does not cause substantial hardship to the occupants.

\section{Acknowledgement}

I would like to acknowledge and extend my heartfelt gratitude to The Ministry of Education and Universiti Teknologi Malaysia for the financial assistance in funding this research. My sincere thank to all my colleagues who kindly provided valuable and helpful comments of this paper.

\section{References}

Bhatta, B. (2009). Analysis of urban growth pattern using remote sensing and GIS: A case study of Kolkata. India International Journal of Remote Sensing, 4733-4746

Bogdon, A. S., \& Can, A., (1997). Indicators of local housing affordability: Comparative and spatial approaches. Real Estate Economics 1997, 25(1), 43-80.

Canada Mortgage and Housing Corporation (2008). Affordable Housing. Retrieved May 22, 2014, from: http://www.bcnpha.ca/media/ Research/affordable\%20housing\%20backgrounder09.pdf

Chazal, J. (2010). A systems approach to livability and sustainability: Defining terms and mapping relationships to link desires with ecological opportunities and constraints. Systems Research and Behavioral Science, 27(5) 585-597.

Disney, J. (2006). Over our heads: Housing costs \& Australian families. Australian Quarterly, 78(2), 4-11.

ECOHH, (2014). Home Safe Home: Affordable Housing and Safety. Retrieved December 4, 2014, from: http://www.ecohh.ca/index.html

HIA Economics Group, (2010). House price to income ratios in Australia. Retrieved on 10 November, 2014, from: http://economics.hia.com.au/media/House\%20price\%20to\%20income\%20ratio\%20-\%20FINAL.pdf

Long, D., \& Hutchins, M. (2003). A Toolkit of Indicators of Sustainable Communities. The Housing Corporation and the European Institute for Urban Affairs.

Lowe et al. (2013). Livable, Healthy, and Sustainable: What Are the Key Indicators for Melbourne Neighborhoods? Retrieved, November 10, 2014, from: http://mccaugheycentre.unimelb.edu.aul_data/assets/pdf_file/0005/799592/Research_Paper_1_-_Liveability_ Indicators_3.pdf

Manitoba, (2012). All aboard: Manitoba's poverty reduction \& social inclusion strategy. Retrieved November 10, 2014, from: http://www.gov.mb.ca/fs/allaboard/pubs/strategy_paper.pdf

Maribyrnong City Council (2008). REAL Housing Affordability Strategy 2008-2012 Footscray.

Martin, D., \& Joomis, K. (2007). Building Teachers: A Constructivist Approach to Introducing Education (pp. 72-75). Belmont, CA: Wadsworth.

Milligan V., Phibbs P., Gurran N. \& Fagan K. (2007). Approaches to Evaluation of Affordable Housing Initiatives in Australia, National Research Venture 3: Housing affordability for lower income. Australians Research Paper No. 7, Australian Housing and Urban Research Institute.

Meyers, D. (2006). Economics \& property: the estates gazette guide: Estates Gazette .2nd ed. London

Victorian Competition and Efficiency Commission (2008). A state of livability: An enquiry into enhancing Victoria's livability, Final report, 2008. Melbourne, Victoria: Victorian Competition and Efficiency Commission.

World Commission on Environment and Development, (1987). Our Common Future. Oxford: Oxford University Press. 